\title{
Comparing the rehydration potential of different milk-based drinks to a carbohydrate-electrolyte beverage
}

\author{
Ben Desbrow, Sarah Jansen, Abby Barrett, Michael D. Leveritt, and Christopher Irwin
}

\begin{abstract}
The aim of this study was to compare the rehydration potential of a carbohydrate-electrolyte beverage with several varieties of milk following exercise-induced fluid losses. Fifteen male participants (age $24.9 \pm 5.5$ years, height $179.3 \pm 4.9 \mathrm{~cm}$, body mass $75.8 \pm 6.6 \mathrm{~kg}($ mean \pm SD) ) lost $2.0 \% \pm 0.2 \%$ body mass through intermittent cycling before consuming a different beverage on 4 separate occasions. Drinks included cow's milk $\left(286 \mathrm{~kJ} \cdot 100 \mathrm{~mL}^{-1}\right)$, soy milk $\left(273 \mathrm{~kJ} \cdot 100 \mathrm{~mL}^{-1}\right)$, a milk-based liquid meal supplement (Sustagen Sport (Nestle); $417 \mathrm{~kJ} \cdot 100 \mathrm{~mL}^{-1}$ ), and a sports drink (Powerade (Coca Cola Ltd); $129 \mathrm{~kJ} \cdot 100 \mathrm{~mL}{ }^{-1}$ ). Beverages were consumed over $1 \mathrm{~h}$ in volumes equivalent to $150 \%$ of body mass loss. Body mass, blood and urine samples, and measures of gastrointestinal tolerance were obtained before and hourly for $4 \mathrm{~h}$ after beverage consumption. Net body mass at the conclusion of each trial was significantly less with Powerade $(-1.37 \pm 0.3 \mathrm{~kg})$ than with cow's milk $(-0.92 \pm 0.48 \mathrm{~kg})$, soy milk $(-0.78 \pm 0.37 \mathrm{~kg})$, and Sustagen Sport $(-0.48 \pm 0.39 \mathrm{~kg})$. Net body mass was also significantly greater for Sustagen Sport compared with cow's milk trials, but not soy milk. Upon completion of trials, the percentage of beverage retained was Sustagen Sport $65.1 \% \pm 14.7 \%$, soy milk $46.9 \% \pm 19.9 \%$, cow's milk $40.0 \% \pm 24.9 \%$, and Powerade $16.6 \% \pm 16.5 \%$. Changes in plasma volume and electrolytes were unaffected by drink treatment. Subjective ratings of bloating and fullness were higher during all milk trials compared with Powerade whereas ratings of overall thirst were not different between beverages. Milk-based drinks are more effective rehydration options compared with traditional sports drinks. The additional energy, protein, and sodium in a milkbased liquid meal supplement facilitate superior fluid recovery following exercise.
\end{abstract}

Key words: hydration, diet, sports nutrition, exercise.

Résumé : Cette étude se propose de comparer le potentiel de réhydratation d’une boisson contenant des sucres et des électrolytes à quelques variétés de boissons lactées à la suite de la perte de liquides corporels suscitée par l'exercice physique. Quinze hommes (moyenne \pm écart-type : $24,9 \pm 5,5$ ans, $179,3 \pm 4,9 \mathrm{~cm}, 75,8 \pm 6,6 \mathrm{~kg}$ ) perdent $2,0 \pm 0,2 \%$ de leur masse corporelle en pédalant par intermittence préalablement à la consommation de boissons différentes en quatre occasions distinctes. Les liquides consommées sont : lait de vache $\left(286 \mathrm{~kJ} \cdot 100 \mathrm{~mL}^{-1}\right)$, lait de soja $\left(273 \mathrm{~kJ} \cdot 100 \mathrm{~mL} \mathrm{~L}^{-1}\right)$, supplément de repas liquide à base de lait (Sustagen Sport; $417 \mathrm{~kJ} \cdot 100 \mathrm{~mL}^{-1}$ ) et boisson pour sportif (Powerade; $129 \mathrm{~kJ} \cdot 100 \mathrm{~mL}-1$ ). Les sujets consomment en $1 \mathrm{~h}$ des quantités équivalant à $150 \%$ de la masse corporelle perdue. On évalue la masse corporelle, des échantillons de sang et d'urine et la tolérance gastro-intestinale avant et aux heures pendant quatre heures après la consommation de la boisson. À la fin de chaque essai, la masse corporelle nette est significativement inférieure dans la condition Powerade $(-1,37 \pm 0,3 \mathrm{~kg})$ comparativement aux autres conditions : lait de vache $(-0,92 \pm 0,48 \mathrm{~kg})$, lait de soja $(-0,78 \pm 0,37 \mathrm{~kg})$ et Sustagen Sport $(-0,48 \pm 0,39 \mathrm{~kg})$. La masse corporelle est aussi significativement supérieure dans la condition Sustagen Sport comparativement à la condition lait de vache, mais pas par rapport à la condition lait de soja. À la fin de chacun des essais, le pourcentage de boisson retenue est : Sustagen Sport 65,1 \pm $14,7 \%$, lait de soja $46,9 \pm 19,9 \%$, lait de vache $40,0 \pm 24,9 \%$ et Powerade $16,6 \pm 16,5 \%$. La variation du volume plasmatique et de la concentration des électrolytes n'est pas affectée par le genre de boisson. Les sensations de ballonnement et de satiété sont plus marquées dans toutes les conditions comprenant du lait comparativement à la condition Powerade; les sensations de soif ne diffèrent pas d'une condition à l'autre. Les boissons à base de lait sont plus efficaces sur le plan de la réhydratation comparativement aux boissons traditionnelles pour sportifs. L'énergie, les protéines et le sodium en plus contenus dans les suppléments liquides à base de lait procurent une plus grande récupération des fluides après un exercice. [Traduit par le Rédaction]

Mots-clés : hydratation, diète, nutrition sportive, exercice physique.

\section{Introduction}

During exercise, sweat output often exceeds fluid intake, producing a fluid deficit or hypohydration. Before recommencing exercise, the hypohydrated athlete is encouraged to consume beverages to restore all fluids and electrolytes that were lost (Sawka et al. 2007). This is because hypohydration impairs performance in both high-intensity exercise (Armstrong et al. 1985; Moquin and Mazzeo 2001; Walsh et al. 1994) and endurance exercise (Ebert et al. 2007), as well as applied motor skills (Devlin et al. 2001) and some cognitive performance measures (Tomporowski et al. 2007), particularly when the level of hypohydration exceeds $2 \%$ of body mass. Consequently, it is important to investigate factors that

Received 13 May 2014. Accepted 8 July 2014.

B. Desbrow. School of Allied Health Sciences, Griffith University, Gold Coast, Australia; Research Centre for Health Practice Innovation, Griffith Health Institute, Griffith University, Gold Coast, Australia.

S. Jansen and A. Barrett. School of Allied Health Sciences, Griffith University, Gold Coast, Australia.

M.D. Leveritt. School of Allied Health Sciences, Griffith University, Gold Coast, Australia; School of Human Movement Studies, University of

Queensland, Brisbane, Australia.

C. Irwin. Research Centre for Health Practice Innovation, Griffith Health Institute, Griffith University, Gold Coast, Australia.

Corresponding Author: Ben Desbrow (e-mail: b.desbrow@griffith.edu.au). 
Table 1. Trial beverage nutrient profiles.

\begin{tabular}{llllll}
\hline Beverage & $\begin{array}{l}\text { Energy } \\
\left(\mathrm{kJ} \cdot 100 \mathrm{~mL}^{-1}\right)\end{array}$ & $\begin{array}{l}\text { Protein } \\
\left(\mathrm{g} \cdot 100 \mathrm{~mL}^{-1}\right)\end{array}$ & $\begin{array}{l}\text { Fat } \\
(\mathrm{g} \cdot 100 \mathrm{~mL}\end{array}$ & $\begin{array}{l}\mathrm{CHO} \\
\left(\mathrm{g} \cdot 100 \mathrm{~mL}^{-1}\right)\end{array}$ & $\begin{array}{l}\mathrm{Na}^{+} \\
\left(\mathrm{mg}^{\prime} \cdot 100 \mathrm{~mL}\right.\end{array}$ \\
\hline Cow's milk (Paul's) & 286 & 3.6 & 3.8 & 4.9 & 41 \\
Soy milk (Sanitarium So Good) & 273 & 3.2 & 3.5 & 5.1 & 45 \\
LiquiLiquid meal supplement (Sustagen Sport) & 417 & 6.5 & 0.2 & 17.6 & 67 \\
CHO-electrolyte drink (Powerade) & 129 & 0 & 0 & 7.3 & 28 \\
\hline
\end{tabular}

Note: $\mathrm{CHO}$, carbohydrate.

may enhance a beverage's ability to quickly restore fluid and electrolyte balance after exercise.

Consumption of dilute fluids, such as plain water, after exercise leads to a decline in plasma osmolality and sodium concentration, resulting in increased rates of fluid excretion, potentially compromising rehydration (Shirreffs et al. 2007a). However, certain nutrients have been demonstrated to improve a beverage's ability to restore fluid balance after exercise. First, the addition of sodium to a postexercise beverage will cause greater fluid retention (Merson et al. 2008; Nose et al. 1988; Shirreffs et al. 1996). The addition of carbohydrate to a rehydration beverage can also cause modest increases in fluid retention following exercise (Evans et al. 2009; Osterberg et al. 2010). Finally, protein has been shown to aid in fluid retention when added to postexercise rehydration beverages (James et al. 2011; Seifert et al. 2006).

Milk is a popular beverage that contains sodium, carbohydrate, and protein. Indeed, cow's milk has been demonstrated to be more effective for postexercise rehydration when compared with traditional sports drinks (Shirreffs et al. 2007b; Watson et al. 2008). Cow's milk consumption after exercise results in $40 \%-50 \%$ less urine output than the same volume of a sports drink or water (Shirreffs et al. 2007b; Watson et al. 2008). Milk could therefore be an effective alternative for those attempting to rehydrate rapidly after exercise.

The effectiveness of milk as a rehydration solution can be related to a number of its constituents. Cow's milk is naturally high in sodium; however, the addition of sodium to milk provides no further benefit to fluid restoration following exercise (Shirreffs et al. $2007 \mathrm{~b}$ ). Adding $25 \mathrm{~g}$ of milk protein to a traditional carbohydrateelectrolyte solution enhances fluid retention after exercise compared with an isocaloric beverage devoid of protein (James et al. 2011). In contrast, a similar study that investigated the effect of 15-g whey protein isolate failed to demonstrate similar improvement of postexercise rehydration (James et al. 2012). When individual constituents of milk beverages are investigated in isolation, the effectiveness on rehydration appears less convincing (Ishihara et al. 2013). This suggests that greater emphasis should be placed on investigating the rehydration potential of milk, as it is typically consumed.

While cow's milk is widely available, relatively inexpensive, and well-liked, it cannot be consumed by all individuals. For instance, it is well known that lactase production persists into adult life in some people but not in others (Ingram et al. 2009). Furthermore, alternative fortified milk-based products (liquid meal supplements) are often promoted to athletes to enhance muscle refuelling and promote muscle protein synthesis while providing a convenient portable option that does not require refrigeration. The rehydration potential of these milk alternatives in comparison with cow's milk and carbohydrate-electrolyte beverages remains unknown. Therefore, the aim of this study was to compare the rehydration effectiveness of 4 beverages - a carbohydrateelectrolyte drink, cow's milk, an energy-, protein-, and sodiummatched soy milk, and a commercially available milk-based liquid meal supplement - following exercise-induced fluid loss.

\section{Materials and methods}

\section{Experimental design}

This study involved a cross-over design with each participant completing 4 different experimental trials. The order of treatment was randomized using an incomplete Latin-square design, and each trial was separated by at least 7 days. The 4 beverages investigated were cow's milk, soy milk, a high-protein milk-based formulated supplementary sports food (Sustagen Sport; Nestle), and a carbohydrate-electrolyte sports drink (Powerade; Coca Cola Ltd). Each experimental trial involved participants exercising until body mass was reduced by approximately $2 \%$. After the exercise period, participants consumed a total volume of beverage equal to $150 \%$ of fluid lost. The total volume of beverage was required to be consumed in a 1-h period. Body mass and blood and urine samples and measures of gastrointestinal tolerance were then collected during a 4-h period in which participants rested in the laboratory.

\section{Participants}

Twenty healthy and recreationally active males, who all reported tolerance to lactose, volunteered to participate in this study. The number of participants was selected following a sample size calculation ( $G^{*}$ Power version 3.0). The results of Shirreffs et al. (2007) indicated the difference in net fluid balance between a carbohydrate-electrolyte beverage and milk was large (effect size of 2.6). To be conservative, we anticipated an effect size of 1.0 and with a power of $80 \%$ and $\alpha=0.05$; the calculation suggested that a sample size of 9 participants was required. Fifteen subjects were recruited to accommodate some attrition because of the experimental burden. The investigation received approval from the Griffith University Human Research Ethics Committee and conformed to its policy statement regarding the use of human subjects and written informed consent.

\section{Beverage treatments}

Participants consumed 1 of 4 beverage solutions in each of the 4 experimental trials. The beverages were (i) a commercially available carbohydrate-electrolyte sports drink (Powerade), (ii) soy milk (So Good Regular, Sanitarium), (iii) cow's milk (Pauls Full Cream, Parmalat), or (iv) a high-carbohydrate, high-protein liquidmeal supplement (Sustagen Sport). The particular brands of soy and cow's milk beverages were chosen as they have similar amounts of energy, protein, fat, carbohydrate, and sodium per serving. The energy, macronutrient, and sodium composition of each beverage is outlined in Table 1 .

\section{Procedures}

Participants arrived at the laboratory in the morning following an overnight fast. Participants were asked to abstain from alcohol consumption for $24 \mathrm{~h}$ and caffeine-containing products (including foods and beverages) for $12 \mathrm{~h}$ prior to each trial. In addition, participants were required to refrain from moderate to strenuous activity $12 \mathrm{~h}$ prior to the trials and were encouraged to keep food intake as consistent as possible in the $24 \mathrm{~h}$ prior to each trial. Compliance with these pre-trial standardization procedures was confirmed verbally on arrival to the laboratory.

Prior to commencing exercise a urine sample was collected from each participant, urine specific gravity (USG; Palette Digital Refractometer, ATAGO, USA) was measured to determine hydration status. Participants that were not adequately hydrated on arrival to the laboratory (USG > 1.020) were required to consume a bolus of water and rest in the laboratory until a further urine sample could be produced indicating a USG recording below the 
threshold for euhydration. Only 3 participants required additional water and on each occasion they consumed $300 \mathrm{~mL}$.

Initial nude body mass was measured and participants began exercising on a cycle ergometer (Monark Ergomedic 828E, GIH, Sweden) at $70 \%-80 \%$ of their age-predicted maximum heart rate until $\sim 1.8 \%$ of their initial body mass was lost. Participants exercised in heavy clothing to encourage sweat loss. Subsequent nude body mass was measured at regular intervals until the required body mass was lost, at which point the subject stopped cycling to allow the remainder of mass loss to occur throughout the cool down. If $\sim 1.8 \%$ body mass deficit was not achieved subjects were instructed to continue exercising until this goal was reached. A rest period of 30 min occurred after the exercise phase to allow subjects to have a cool shower, return to the laboratory, and rest. A final nude body mass was then taken to determine the volume of fluid required for consumption. Trials were conducted at the same time of day in a stable laboratory environment $\left(22 \pm 2{ }^{\circ} \mathrm{C}\right.$, $60 \%-70 \%$ relative humidity).

Over the next $60 \mathrm{~min}$, the subjects ingested one of the rehydration beverages. The entire beverage volume, equal to $150 \%$ of the change in body mass, was divided into 4 equal parts, each of which was consumed over a 15 -min period. All beverages aliquots were served cold $\left(\sim 4{ }^{\circ} \mathrm{C}\right)$, immediately from the refrigerator. For the subsequent 4-h observation period, subjects remained within the laboratory and were seated except for essential movements.

\section{Fluid balance and retention}

Total urine loss was calculated from the accumulated urine output in the period from the commencement of drinking until the end of the observation period (i.e., $5 \mathrm{~h}$ total). Participants were permitted to urinate as required throughout the observation period. Urine per hour was calculated following requested voiding at the conclusion of each hour throughout this 5-h period. Net body mass (a proxy for net fluid balance) was calculated by subtracting the body mass (post voiding) from the initial body mass with fecal losses being excluded via immediate pre-post body mass measurements. When used across an acute time period, it is proposed that body mass changes take into account urinary losses, sweat loss, and other insensible losses and arrive at the value of complete hydration status (Armstrong 2005). Finally, a value for fluid retention was calculated by the following equation:

$$
\begin{aligned}
& \text { fluid retention }=[(\text { volume of beverage consumed } \\
& \quad-\text { urine output after } 4 \mathrm{~h}) / \text { volume of beverage consumed }] \times 100
\end{aligned}
$$

\section{Blood measures}

Prior to each blood sample, participants were asked to rest in a supine position for at least $15 \mathrm{~min}$ to minimize the effects of postural changes on the redistribution of water between the major bodily compartments (Lambert et al. 1992). Once rested, a 2-mL blood sample was drawn from an antecubital vein. Blood samples were collected prior to exercise, following exercise, at the conclusion of drinking, $1 \mathrm{~h}$ into the observation period, and at the end of the observation period $(4 \mathrm{~h})$. Samples were stored in lithium heparin vacutainers before being processed through an iSTAT blood analyzer (i-STAT 1 Analyzer, Abbott, USA) for the measurement of sodium, potassium, glucose, haemoglobin, and haematocrit concentrations. Plasma volume changes were calculated according to the methods described by Dill and Costill (1974).

\section{Subjective measures}

Questionnaires were conducted during the rehydration phase of the study to examine palatability of the different beverages and gastrointestinal (GI) symptoms. The palatability questionnaire was administered with the second and last of the 4 beverages aliquots and consisted of ratings of overall pleasantness, saltiness, sweetness, and bitterness. The GI questionnaire was conducted prior to the first beverage (baseline), at $15 \mathrm{~min}$ following the sec- ond and the last drink, and at hourly intervals until the end of the observation period. Participants were asked to rate feelings of thirst, fullness, hunger, energy, tiredness, alertness, and dryness of mouth. All measures were conducted on a $100-\mathrm{mm}$ visual analogue scale (VAS), ranging from "not at all" to "a lot", administered using a laptop computer (Marsh-Richard et al. 2009).

\section{Data analysis}

All statistical procedures were performed using SPSS Statistics for Windows, version 21.0 (IBM Corp. 2012, Armonk, N.Y., USA). Statistical analysis for each of the main dependent variables regarding hydration potential of beverages and VAS subjective responses were conducted using 2-way (beverage $\times$ time) repeatedmeasures ANOVA. Post hoc analysis using Bonferroni correction factor was performed on all significant $F$ ratios. Statistical significance was accepted at $p<0.05$. All data are reported as means \pm SD unless otherwise specified.

\section{Results}

\section{Standardization procedures}

Five recruited participants withdrew either immediately prior to or following their first experimental trial. Two participants withdrew because of competing time commitments, 1 failed to respond following recruitment despite repeated contact attempts, and 2 disliked the experimental protocol having completed their first trial. Hence, 15 participants, (age, $24.9 \pm 5.5$ years; height, $179.3 \pm 4.9 \mathrm{~cm}$; body mass, $75.8 \pm 6.6 \mathrm{~kg}$ ) successfully completed all 4 experimental trials.

All participants arrived to the laboratory having stated compliance with the pre-trial dietary and exercise control conditions. According to USG threshold measurements, all participants commenced trials in a state of euhydration (cow's milk $=1.012 \pm 0.01$, soy milk $=1.010 \pm 0.01$, Sustagen Sport $=1.012 \pm 0.01$, Powerade $=$ $1.015 \pm 0.01)$ and participants commenced exercise with similar starting body masses (cow's milk $=75.8 \pm 6.7 \mathrm{~kg}$, soy milk $=75.5 \pm$ $6.6 \mathrm{~kg}$, Sustagen Sport $=75.7 \pm 6.7 \mathrm{~kg}$, Powerade $=76.1 \pm 6.7 \mathrm{~kg}$ ). Exercise time was similar between trials (cow's milk $=63.0 \pm$ $6 \mathrm{~min}$, soy milk $=61.3 \pm 3 \mathrm{~min}$, Sustagen Sport $=61.5 \pm 13 \mathrm{~min}$, Powerade $=62.2 \pm 4 \mathrm{~min}, p=0.365)$. Exercise induced a similar reduction in body mass (cow's milk $=2.0 \pm 0.3 \%$, soy milk $1.9 \pm$ $0.2 \%$, Sustagen Sport $=1.9 \% \pm 0.2 \%$, Powerade $=2.0 \% \pm 0.3 \%$ ).

\section{Beverage volume and consumption}

Similar beverage volumes were consumed across all experimental conditions (cow's milk $=2.2 \pm 0.4 \mathrm{~L}$, soy milk $=2.2 \pm 0.2 \mathrm{~L}$, Sustagen Sport $=2.2 \pm 0.3 \mathrm{~L}$, Powerade $=2.2 \pm 0.3 \mathrm{~L}$ ). Because of volume tolerance issues, approximately half the participants required slightly longer than the allocated $1 \mathrm{~h}$ to consume the beverages. The longest time required to consume the test beverages for all trials was $75 \mathrm{~min}$. For all trials where $>1 \mathrm{~h}$ was required to complete beverage ingestion, outcome measures were taken relative to the commencement of drinking. Two trials had to be repeated because of emesis.

\section{Outcome measures}

Net body mass results are displayed in Fig. 1. All experimental trials concluded with participants in a state of negative net body mass relative to pre-exercise values (Sustagen Sport $=-0.48 \pm$ $0.39 \mathrm{~kg}$, soy milk $=-0.78 \pm 0.37 \mathrm{~kg}$, cow's milk $=-0.92 \pm 0.48 \mathrm{~kg}$, Powerade $=-1.37 \pm 0.3 \mathrm{~kg}$ ). The consumption of Powerade resulted in significantly greater net body mass loss when compared with all milk beverages (Powerade vs cow's milk, $p<0.01$; Powerade vs soy milk, $p<0.01$; Powerade vs Sustagen Sport, $p<0.01$ ). Differences between Powerade and all milk beverages were evident $2 \mathrm{~h}$ after beverage consumption and following $1 \mathrm{~h}$ in the Susagen Sport trial. Net body mass was also significantly greater for Sustagen Sport compared with cow's milk, but not soy milk (cow's milk vs Sustagen Sport, $p<0.05$; soy milk vs Sustagen Sport, $p=0.158$ ). The 
Fig. 1. Net body mass responses to the consumption of 4 beverages following an exercise-induced fluid loss. a, Statistically significant difference between Powerade (Coca Cola Ltd) and Sustagen Sport (Nestle). b, Statistically significant difference between Powerade and cow's milk. c, Statistically significant difference between Powerade and soy milk. d, Statistically significant difference between cow's milk and Sustagen Sport. Post Ex, postexercise; Pre Ex, pre-exercise.

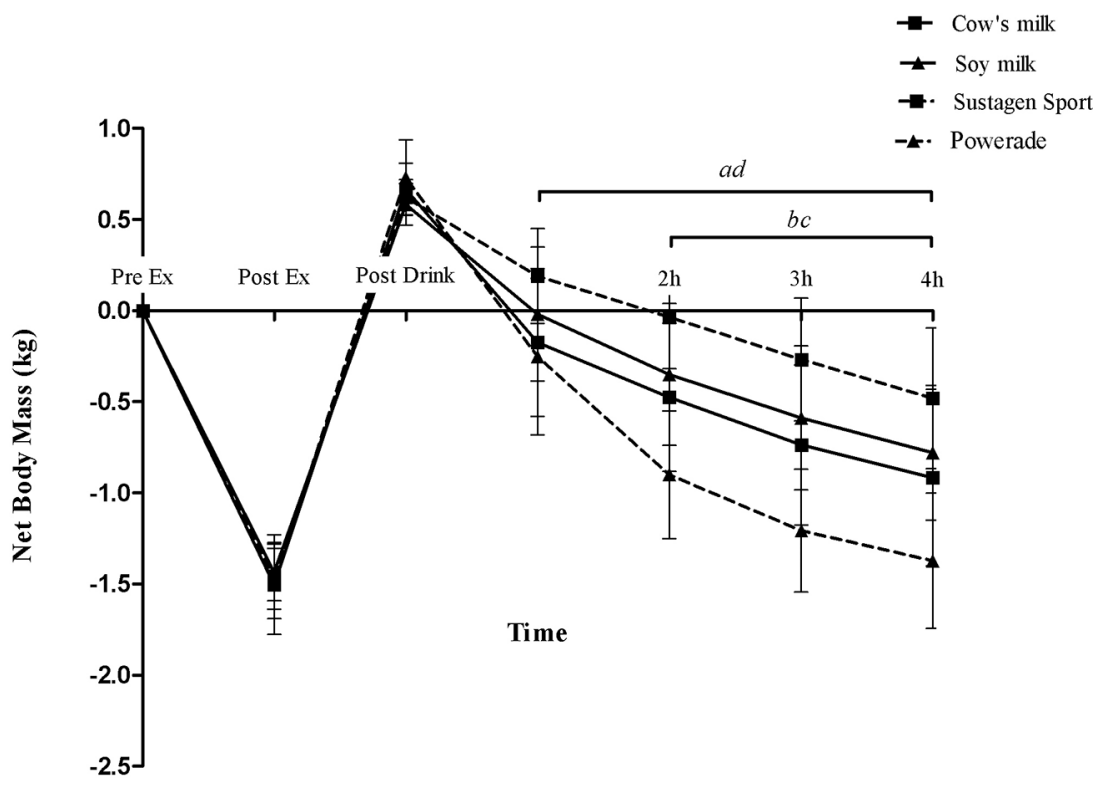

differences between cow's milk and Sustagen Sport were evident $1 \mathrm{~h}$ after beverage consumption.

The total urine volumes and percentage of fluid retained for each trial are shown in Table 2. Hourly urine volumes for each trial are shown in Fig. 2. All milk trials concluded with significantly less urine output compared with the Powerade trial (Powerade $=1834 \pm 427 \mathrm{~mL}$ vs cow's milk $=1338 \pm 578 \mathrm{~mL}(p<0.01)$, vs soy milk $=1144 \pm 446 \mathrm{~mL}(p \leq 0.01)$, vs Sustagen Sport $=771 \pm 367 \mathrm{~mL}$ $(p<0.01))$. Additionally, the total urine output following the Sustagen Sport trial was significantly less than observed in cow's milk $(p<0.01)$ and soy milk $(p<0.05)$ trials. Peak urine output occurred in the first hour of recovery for all trials (Powerade $=$ $868 \pm 362 \mathrm{~mL}$, cow's milk $=747 \pm 409 \mathrm{~mL}$, soy milk $=570 \pm 361 \mathrm{~mL}$, Sustagen Sport $=348 \pm 272 \mathrm{~mL}$ ) and remained significantly higher in the second hour for Powerade compared with the milk trials.

Table 3 displays changes in plasma volume across time. As expected, plasma volume decreased after exercise-induced dehydration. Rehydration resulted in an increase in plasma volume from postexercise measures. Plasma volume shifts from the end of rehydration to the conclusion of the observation period did not differ between trials (all $p>0.05$ ).

Blood measures of sodium, potassium, and glucose remained within appropriate reference ranges throughout each trial. The only difference in blood measures between trials occurred in glucose concentration at the completion of trials (Fig. 3). Soy milk resulted in higher blood glucose concentrations than the 3 other beverages (soy milk $=5.25 \pm 0.42 \mathrm{mmol} \cdot \mathrm{L}^{-1}$, cow's milk $=4.76 \pm$ $0.18 \mathrm{mmol} \cdot \mathrm{L}^{-1}$, Sustagen Sport $=4.67 \pm 0.39 \mathrm{mmol} \cdot \mathrm{L}^{-1}$, Powerade $=$ $\left.4.60 \pm 0.37 \mathrm{mmol} \cdot \mathrm{L}^{-1}, p<0.05\right)$.

Palatability ratings revealed participants considered the Powerade beverage to be the most pleasant and the soy milk the least pleasant when compared with the other beverages (end of drinking rating, Powerade $=83 \pm 11 \mathrm{~mm}$, cow's milk $=53 \pm 22 \mathrm{~mm}$, soy milk $=14 \pm$ $18 \mathrm{~mm}$, Sustagen Sport $=53 \pm 28 \mathrm{~mm}$, all $p>0.05$ ). Sustagen Sport and Powerade beverages were rated significantly sweeter than the cow's milk and soy milk beverages at both rehydration phase check points $(p<0.05)$. Subjective ratings of saltiness and bitterness did not differ between beverage treatments.

GI tolerance questions revealed that ratings of thirst increased in all trials throughout the recovery phase $(p<0.01)$ but were not
Table 2. Cumulative urine output and fluid retention at the conclusion of a 4 -h period in response to the consumption of 4 beverages following an exercise-induced fluid loss.

\begin{tabular}{llllll}
\hline & \multicolumn{2}{l}{ Output $(\mathrm{mL})$} & & \multicolumn{2}{c}{ Fluid retention $(\%)$} \\
\cline { 2 - 3 } Beverage & Mean & SD & & Mean & SD \\
\hline Powerade & $1833 \mathrm{~b}$ & 427 & & $16.6 \mathrm{~b}$ & 16.5 \\
Cow's milk & $1338 \mathrm{ab}$ & 578 & & $40.0 \mathrm{ab}$ & 24.9 \\
Soy milk & $1143 \mathrm{ab}$ & 446 & & $46.9 \mathrm{ab}$ & 19.9 \\
Sustagen Sport & $771 \mathrm{a}$ & 367 & & $65.1 \mathrm{a}$ & 14.7 \\
\hline
\end{tabular}

Note: Fluid retention $=$ (volume of beverage consumed - urine output after $4 \mathrm{~h}) \times 100$. a, Mean statistically significantly different from Powerade. b, Mean statisitically significantly different from Sustagen Sport.

different between the beverages $(p>0.05)$. A significant effect of time $(p<0.01)$, beverage $(p<0.01)$, and a time $\times$ beverage $(p<0.05)$ interaction was observed in subjective ratings of fullness. Post hoc analysis revealed higher ratings of fullness for Sustagen Sport compared with all other beverages and that both cow's milk and soy milk were rated higher than Powerade across all time points. A significant effect of time $(p<0.01)$, beverage $(p<0.01)$, and a time $x$ beverage $(p<0.05)$ interaction was observed in subjective ratings of hunger. Post hoc analysis revealed higher ratings following the Powerade trial compared with all other beverages until the final hour of the recovery period. Ratings of hunger following the cow's milk trial were also higher than for both Sustagen Sport and soy milk across this period. No significant effects were observed for any of the other subjective rating measures.

\section{Discussion}

The purpose of this study was to compare the effectiveness of soy milk and a commercially available milk-based liquid meal supplement with cow's milk and a carbohydrate-electrolyte drink for replacing exercise-induced fluid losses. The results of this investigation demonstrate that consumption of a milk-based liquid meal supplement following exercise results in improved fluid retention when compared with cow's milk, soy milk, and a carbohydrateelectrolyte drink. Additionally, cow's milk and soy milk were similarly effective at enhancing fluid restoration in comparison with the carbohydrate-electrolyte drink. 
Fig. 2. Hourly urine output responses to the consumption of 4 beverages following an exercise-induced fluid loss. a, Statistically significant difference between Powerade (Coca Cola Ltd) and Sustagen Sport (Nestle). b, Statistically significant difference between Powerade and cow's milk. c, Statistically significant difference between Powerade and Soy milk. d, Statistically significant difference between cow's milk and Sustagen.

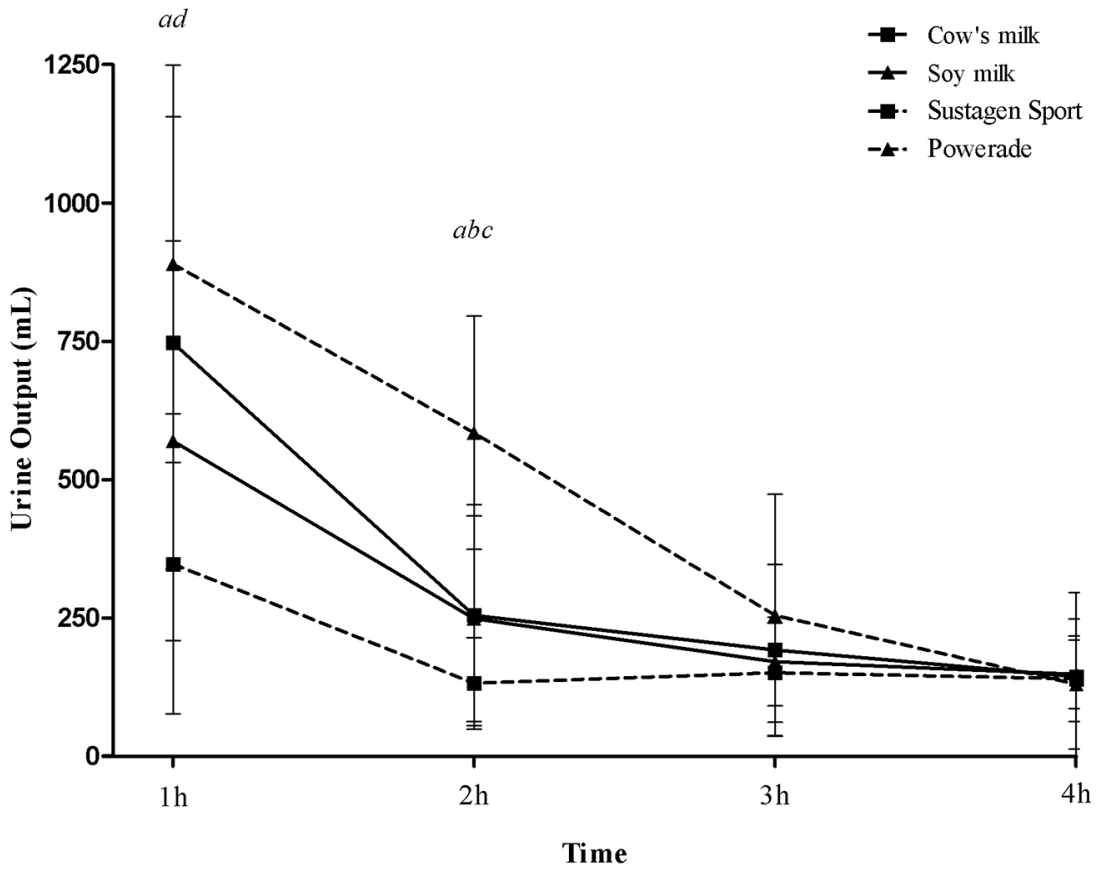

Table 3. Change in plasma volume throughout an observation period in response to the consumption of 4 beverages following an exercise-induced fluid loss.

\begin{tabular}{|c|c|c|c|c|c|c|c|c|}
\hline \multirow[b]{2}{*}{ Trial } & \multicolumn{2}{|c|}{$\begin{array}{l}\text { Pre-Ex to } \\
\text { Post-Ex (\%) }\end{array}$} & \multicolumn{2}{|c|}{$\begin{array}{l}\text { Post-Ex to } \\
\text { rehydration (\%) }\end{array}$} & \multicolumn{2}{|c|}{$\begin{array}{l}\text { Rehydration to } \\
1 \mathrm{~h}(\%)\end{array}$} & \multicolumn{2}{|c|}{$\begin{array}{l}\text { Rehydration to } \\
4 \mathrm{~h}(\%)\end{array}$} \\
\hline & Mean & SD & Mean & SD & Mean & SD & Mean & SD \\
\hline Powerade & -5.45 & 9.0 & 5.49 & 20.7 & 1.59 & 14.8 & 2.70 & 6.8 \\
\hline Cow's milk & -1.86 & 6.3 & -1.49 & 2.0 & 7.30 & 9.4 & 4.01 & 5.0 \\
\hline Soy milk & -4.09 & 6.6 & -2.00 & 3.6 & 4.69 & 8.4 & 4.99 & 7.5 \\
\hline Sustagen Sport & -5.73 & 9.4 & -0.19 & 6.3 & 2.80 & 4.9 & 6.28 & 9.2 \\
\hline
\end{tabular}

Note: Plasma volume changes calculated using the methods of Dill and Costill (1974). No statistically significant differences were observed. Post-Ex, postexercise; Pre-Ex, pre-exercise.

The rehydration potential of beverages used in the current study demonstrated dose-response relationships for total calorie density, total protein, and sodium. Beverage protein and sodium content have previously demonstrated a capacity to positively influence postexercise fluid retention when examined in isolation (James et al. 2011; Maughan and Leiper 1995; Shirreffs et al. 1996). Furthermore, higher caloric meals typically slow the rate of gastric emptying, which is likely to improve the capacity to absorb and retain fluid from the small intestine (Kwiatek et al. 2009). In contrast, the potential of increases in carbohydrate to contribute to fluid loss via effects on fluid delivery have been demonstrated (Jeukendrup et al. 2009). The results from the present study are generally in keeping with these findings. Given that, the intention of this experiment was to explore the rehydration potential of commercially available beverages; the beverages were not precisely matched for energy and macronutrient distribution, making extrapolation to the individual macronutrient effects on fluid restoration difficult.

The cow's milk and soy milk beverages in the current investigation had similar energy, macronutrient distribution, and sodium, but differed in the source of protein (cow's milk protein, and soy protein). Two previous studies to have investigated the impact of milk proteins on postexercise hydration demonstrated improved fluid retention when $25 \mathrm{~g}$ of whole milk protein was added to an isocaloric carbohydrate-electrolyte solution (James et al. 2011) and no effect when a smaller protein dose (15 g) was added as whey-protein isolate (James et al. 2012). Given that we saw similar changes in fluid retention after the consumption of $\sim 66 \mathrm{~g}$ of cow and soy protein within these milk beverages, it is likely that the amount of protein (rather than the source) is a significant factor determining the rehydration potential of a beverage. Furthermore, the results of the present study indicate that the use of soy milk and milk-based meal replacement drinks, which are widely available and do not require refrigeration, offer an effective fluid replacement alternative for individuals intolerant to lactose or lacking the facilities to keep beverages cold.

The design of the current investigation required participants to consume predetermined volumes of temperature-controlled beverages in accordance with rehydration guidelines (Sawka et al. 2007). In the sporting context, athletes typically consume fluids ad libitum and the beverage choice and total volume consumed may be determined by many factors, including thirst, palatability, gastrointestinal tolerance, drink availability, and dietary goals (Minehan et al. 2002; Passe et al. 2000). Therefore, it is important to recognize the practical application of the current results. First, the findings indicate that the traditional sports drink was perceived to be the most pleasant of the beverages and soy milk the least pleasant. While it is possible that the ratings of 
Fig. 3. Blood glucose responses to the consumption of 4 beverages following an exercise-induced fluid loss. a, Statistically significant difference between soy milk and other beverages.

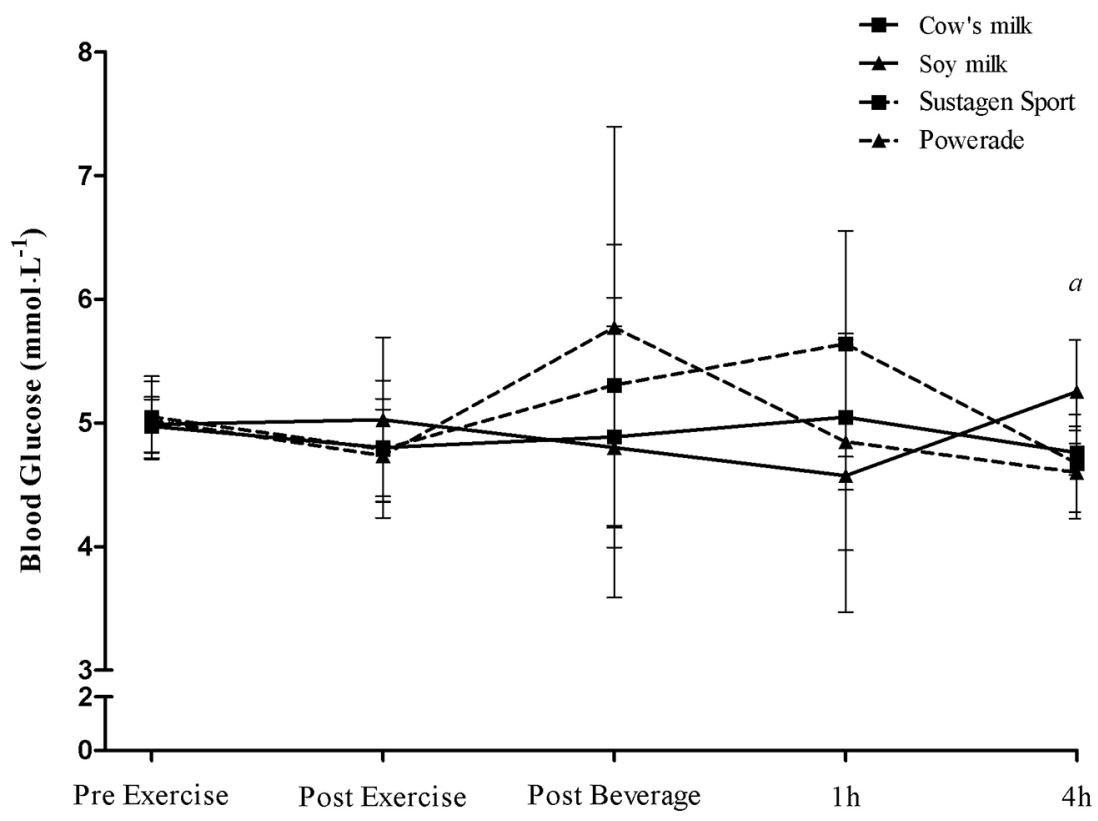

Time

pleasantness associated with soy milk consumption observed in the current study relate to the use of participants who were not regular consumers of soy-based milk products, it is plausible that the use of soy milk-based beverages for rehydration purposes may be compromised by palatability issues. Furthermore, the consumption of large volumes of a high calorie milk-based supplement (often providing $\geq 8000 \mathrm{~kJ}$ ) within $\sim 1 \mathrm{~h}$ of exercise is impractical for many athletes, particular those requiring or habitually consuming a constrained energy intake. With participants reporting increased satiety associated with the higher calorie density beverages within this study, the impact of palatability and tolerance on consumption volumes within an ad libitum environment warrant further examination.

In summary, this investigation further demonstrates the capacity of commercially available milk-based beverages to enhance the replacement of lost fluid following exercise in comparison with carbohydrate-electrolyte drinks. Additionally, the choice of cow's milk over soy milk beverages should be based on personal preference as both have equally effective rehydration potential when matched volumes are consumed.

\section{Acknowledgements}

The authors would like to acknowledge the valuable contribution made by all study participants. Funding was from internal Griffith University support. There are no external funding or conflict of interest to disclose. Author contributions: B.D., S.J., M.D.L., and C.I. were all involved in the conception and design. S.J., A.B., and C.I. were responsible for the acquisition of data. All authors contributed to the analysis and interpretation of data. All authors contributed to drafting the article and revising it critically for important intellectual content. All authors were involved in the final approval of the published version of the manuscript.

\section{References}

Armstrong, L.E. 2005. Hydration assessment techniques. Nutr. Rev. 63(6): S40S54. doi:10.1111/j.1753-4887.2005.tb00153.x.

Armstrong, L.E., Costill, D., and Fink, W. 1985. Influence of diuretic-induced dehydration on competitive running performance. Med. Sci. Sports Exerc. 17(4): 456-461. doi:10.1249/00005768-198508000-00009.

Devlin, L., Fraser, S., Barras, N., and Hawley, J. 2001. Moderate levels of hypohy- dration impairs bowling accuracy but not velocity in skilled cricket players. J. Sci. Med. Sport, 4(2): 179-187. PMID:11548917.

Dill, D., and Costill, D. 1974. Calculation of perecentage changes in volumes of blood, plasma, and red cells in dehydration. J. Appl. Physiol. 37(2): 247-248. PMID:4850854.

Ebert, T.R., Martin, D., Bullock, N., Mujika, I., Quod, M., Farthing, L., et al. 2007. Influence of hydration status on thermoregulation and cycling hill climbing. Med. Sci. Sports Exerc. 39(2): 323-329. doi:10.1249/01.mss.0000247000.86847.de.

Evans, G.H., Shirreffs, S.M., and Maughan, R.J. 2009. Postexercise rehydration in man: the effects of osmolality and carbohydrate content of ingested drinks. Nutrition, 25(9): 905-913. doi:10.1016/j.nut.2008.12.014.

Ingram, C.J.E., Mulcare, C.A., Itan, Y., Thomas, M.G., and Swallow, D.M. 2009. Lactose digestion and the evolutionary genetics of lactase persistence. Hum. Genet. 124(6): 579-591. doi:10.1007/s00439-008-0593-6.

Ishihara, K., Kato, Y., Usami, A., Yamada, M., Yamamura, A., Fushiki, T., and Seyama, Y. 2013. Electrolyte-free milk protein solution influences sodium and fluid retention in rats. J. Nutr. Sci. 2(e8): 1-7. doi:10.1017/jns.2012.24.

James, L.J., Clayton, D., and Evans, G. 2011. Effect of milk protein addition to a carbohydrate-electrolyte rehydration solution ingested after exercise in the heat. Br. J. Nutr. 105: 393-399. doi:10.1017/S0007114510003545.

James, L.J., Gingell, R., and Evans, G.H. 2012. Whey protein addition to a carbohydrate-electrolyte rehydration solution ingested after exercise in the heat. J. Athl. Train, 47(1): 61-66. PMID:22488231.

Jeukendrup, A., Currell, K., Clarke, J., Cole, J., and Blannin, A. 2009. Effect of beverage glucose and sodium content on fluid delivery. Nutr. Metab. (Lond). 6: 9. doi:10.1186/1743-7075-6-9. PMID:19232115.

Kwiatek, M.A., Menne, D., Steingoetter, A., Goetze, O., Forras-Kaufman, Z., Kaufman, E., et al. 2009. Effect of meal volume and calorie load on postprandial gastric function and emptying: studies under physiological conditions by combined fiber-optic pressure measurement and MRI. Am. J. Physiol. Gastrointest. Liver Physiol. 297(5): G894-G901. doi:10.1152/ajpgi.00117.2009.

Lambert, C., Costill, D., McConell, G., Benedict, M., Lambert, G., Robergs, R., and Fink, W. 1992. Fluid replacement after dehydration: influence of beverage carbonation and carbohydrate content. Int. J. Sports Med. 13(4): 285-292. doi:10.1055/s-2007-1021268.

Marsh-Richard, D.M., Hatzis, E.S., Mathias, C.W., Venditti, N., and Dougherty, D.M. 2009. Adaptive Visual Analog Scales (AVAS): a modifiable software program for the creation, administration, and scoring of visual analog scales. Behav. Res. Methods, 41(1): 99-106. doi:10.3758/BRM.41.1.99.

Maughan, R.J., and Leiper, J. 1995. Sodium intake and post-exercise rehydration in man. Eur. J. Appl. Physiol. 71: 311-319. doi:10.1007/BF00240410.

Merson, S.J., Maughan, R.J., and Shirreffs, S.M. 2008. Rehydration with drinks differing in sodium concentration and recovery from moderate exerciseinduced hypohydration in man. Eur. J. Appl. Physiol. 103(5): 585-594. doi:10. 1007/s00421-008-0748-0.

Minehan, M., Riley, M., and Burke, L. 2002. Effect of flavor and awareness of 
kilojoule content of drinks on preference and fluid balance in team sports. Int. J. Sport Nutr. Exerc. Metab. 12(1): 81-92. PMID:11993625.

Moquin, A., and Mazzeo, R. 2001. Effect of mild dehydration on the lactate threshold in women. Med. Sci. Sports Exerc. 32(2): 396-402. PMID:10694123.

Nose, H., Mack, G.W., Shi, X.R., and Nadel, E.R. 1988. Role of osmolality and plasma volume during rehydration in humans. J. Appl. Physiol. 65(1): 325331. PMID:3403476.

Osterberg, K.L., Pallardy, S.E., Johnson, R.J., and Horswill, C.A. 2010. Carbohydrate exerts a mild influence on fluid retention following exercise-induced dehydration. J. Appl. Physiol. 108(2): 245-250. doi:10.1152/japplphysiol.91275. 2008.

Passe, D.H., Horn, M., and Murray, R. 2000. Impact of beverage acceptability on fluid intake during exercise. Appetite, 35: 219-229. doi:10.1006/appe.2000. 0352 .

Sawka, M., Burke, L., Eichner, E., Maughan, R., Montain, S., and Stachenfeld, N. 2007. Exercise and fluid replacement. Med. Sci. Sports Exerc. 39(2): 377-390. doi:10.1249/mss.0b013e31802ca597.

Seifert, J., Harmon, J., and DeClercq, P. 2006. Protein added to a sports drink improves fluid retention. Int. J. Sport Nutr. Exerc. Metab. 16(4): 420-429. PMID:17136943.

Shirreffs, S., Taylor, A., Leiper, J., and Maughan, R. 1996. Post-exercise rehydration in man: effects of volume consumed and drink sodium content. Med. Sci. Sports Exerc. 28(10): 1260-1271. doi:10.1097/00005768-199610000-00009.

Shirreffs, S., Aragon-Vargas, L., Keil, M., Love, T., and Phillips, S. 2007. Rehydration after exercise in the heat: A comparison of 4 commonly used drinks. Int. J. Sports Nut. Ex. Met. 17: 244-258. PMID:17693686.

Shirreffs, S., Watson, P., and Maughan, R. 2007. Milk as an effective post-exercise rehydration drink. Br. J. Nutr. 98(1): 173-180. doi:10.1017/S0007114507695543.

Tomporowski, P., Beasman, K., Ganio, M., and Cureton, K. 2007. Effects of dehydration and fluid ingestion on cognition. Int. J. Sports Med. 28: 891-896. doi:10.1055/s-2007-965004.

Walsh, R.M., Noakes, T.D., Hawley, J.A., and Dennis, S.C. 1994. Impaired highintensity cycling performance time at low levels of dehydration. Int. J. Sports Med. 15(7): 392-398. doi:10.1055/s-2007-1021076.

Watson, P., Love, T., Maughan, R., and Shirreffs, S. 2008. A comparison of the effects of milk and a carbohydrate-electroltye drink on the restoration of fluid balance and exercise capacity in a hot, humid environment Eur. J. Appl. Physiol. 104, 633-642. doi:10.1007/s00421-008-0809-4. 